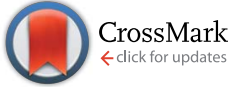

Cite this: RSC Adv., 2014, 4, 42617

Received 19th June 2014

Accepted 13th August 2014

DOI: $10.1039 / c 4 r a 05968 a$

www.rsc.org/advances

\section{Potential of brackish water and brine for energy generation by salinity gradient power-reverse electrodialysis (SGP-RE)}

\author{
Ramato Ashu Tufa, ${ }^{a}$ Efrem Curcio, ${ }^{\text {ab }}$ Willem van Baak, ${ }^{c}$ Joost Veerman, ${ }^{d}$ \\ Simon Grasman, ${ }^{d}$ Enrica Fontananova ${ }^{\mathrm{b}}$ and Gianluca Di Profio ${ }^{\mathrm{b}}$
}

In the present work, a salinity gradient power-reverse electrodialysis (SGP-RE) unit was tested for the production of electrical energy by exploiting the chemical potential of real brackish water and exhaust brine from a solar pond. A cross-flow SGP-RE module (REDstack B.V.), equipped with AEM-80045 and CEM-80050 membranes specifically developed by Fujifilm Manufacturing Europe B.V. within the EU-funded project REAPOWER ("Reverse Electrodialysis Alternative Power Production"), was able to generate a maximum power density (expressed in $\mathrm{W} \mathrm{m}^{-2}$ membrane pair - MP) of $3.04 \mathrm{~W} \mathrm{~m}^{-2} \mathrm{MP}$ when operated with pure $\mathrm{NaCl}$ aqueous solutions $(0.1 \mathrm{M}$ in low concentration compartment - LCC, $5 \mathrm{M}$ in high concentration compartment $-\mathrm{HCC}$ ) at $20{ }^{\circ} \mathrm{C}$ and at a recirculation rate of $20 \mathrm{~L} \mathrm{~h}^{-1}$. However, a drastic reduction to $1.13 \mathrm{~W} \mathrm{~m}^{-2}(-63 \%)$ was observed when feeding the SGP-RE unit with artificial multiion solutions mimicking real brackish water and exhaust brine. Further experimental activity allowed to identify $\mathrm{Mg}^{2+}$ ion as responsible for the significant increase in stack resistance and consequent depletion in SGP-RE performance. Therefore, specific softening treatments of the real solutions should be considered in order to maintain the process efficiency at practical level.

\section{Introduction}

Global demand for energy is increasing at an unsustainable rate mainly due to global economic expansion, population growth and an increasing living standard in emerging countries. As a result, the extensive utilization of available fossil fuels is causing a progressive depletion of these resources and an increase in global $\mathrm{CO}_{2}$ emissions. Renewable energy sources with limited thermal and environmental pollution, and absence of net emission of greenhouse gases and radioactive wastes, are attracting an increasing attention. In particular, reverse electrodialysis (RE) is an emerging technology having the potential to generate energy from salinity power gradients (SGP). In a typical SGP-RE module, cation exchange membranes (CEM) and anion exchange membranes (AEM) are stacked alternately in a module; driven by a concentration gradient, the diffusive flux of ions generates an electrochemical membrane potential recorded as a voltage across electrodes. ${ }^{1}$ From a theoretical point of

\footnotetext{
${ }^{a}$ Department of Environmental and Chemical Engineering, University of Calabria (DIATIC-UNICAL), via P. Bucci CUBO 45A, 87036 Rende, CS, Italy. E-mail: e.curcio@unical.it; Fax:+390984 496655; Tel: +390984 494013

${ }^{b}$ Institute on Membrane Technology of the National Research Council (ITM-CNR), c/o University of Calabria, via P. Bucci, cubo 17/C, 87036 Rende, CS, Italy

'Fujifilm Manufacturing Europe B.V., Oudenstaart 1, 5047 TK, Tilburg, The Netherlands

${ }^{d}$ REDstack B.V., Pieter Zeemanstraat 6, $8606 \mathrm{JR}$, Sneek, The Netherlands
}

view, the value of the voltage from an unloaded RE stack (open circuit voltage - OCV) is predicted by the following equation: ${ }^{2}$

$$
\begin{aligned}
\mathrm{OCV}= & \frac{2 N R T}{F}\left[\frac{\alpha_{\mathrm{AEM}}}{z_{\mathrm{a}}} \ln \left(\frac{\gamma_{\mathrm{a}, \mathrm{HCC}} C_{\mathrm{a}, \mathrm{HCC}}}{\gamma_{\mathrm{a}, \mathrm{LCC}} C_{\mathrm{a}, \mathrm{LCC}}}\right)\right. \\
& \left.+\frac{\alpha_{\mathrm{CEM}}}{z_{\mathrm{c}}} \ln \left(\frac{\gamma_{\mathrm{c}, \mathrm{HCC}} C_{\mathrm{c}, \mathrm{HCC}}}{\gamma_{\mathrm{c}, \mathrm{LCC}} C_{\mathrm{c}, \mathrm{LCC}}}\right)\right]
\end{aligned}
$$

in which $R$ is the universal gas constant $\left(8.314 \mathrm{~J} \mathrm{~mol}^{-1} \mathrm{~K}^{-1}\right), N$ is the number of membrane pairs, $T$ is the temperature $(\mathrm{K}), z$ is the valence, $\alpha$ is the average transport number of counter-ions, $F$ is the Faraday constant (96485 $\mathrm{C} \mathrm{mol}^{-1}$ ), $\gamma$ is the activity coefficient of the ion, and $C$ is the concentration $\left(\mathrm{mol} \mathrm{L}^{-1}\right)$; subscripts a, c, HCC and LCC refer to anion, cation, high concentration compartment and low concentration compartment, respectively.

Previous investigations carried out on aqueous $\mathrm{NaCl}$ solutions, which mimic seawater and river water salinity, reached a power density around $2 \mathrm{~W} \mathrm{~m}^{-2}$ of membrane ${ }^{3-7}$ and energy efficiency around $50 \% .^{8}$ Vermaas et al. (2013) showed that the theoretically obtained Gibbs free energy of mixing seawater $\left(30 \mathrm{~g} \mathrm{~L}^{-1} \mathrm{NaCl}\right)$ and river water $\left(1 \mathrm{~g} \mathrm{~L}^{-1} \mathrm{NaCl}\right)$, both at a flow rate of $1 \mathrm{~m}^{3} \mathrm{~s}^{-1}$ is $1.39 \mathrm{MW}^{8}$

Advantages of SGP-RE operations carried out at high concentration in the HCC have been clearly envisaged in the work of Post et al. (2007); if LCC and HCC are fed with $0.05 \mathrm{M}$ and $5 \mathrm{M} \mathrm{NaCl}$, respectively, the theoretically available amount of 
energy from mixing $1 \mathrm{~m}^{3}$ of diluted and $1 \mathrm{~m}^{3}$ of a concentrated solution at $293 \mathrm{~K}$ increases to $15 \mathrm{MJ} .^{9}$

At present, literature works on RE systems operated under high concentrated solutions like brine are less in number and, most of the work, refer to pure $\mathrm{NaCl}$ aqueous solutions. A power density up to $0.87 \mathrm{~W} \mathrm{~m}^{-2}$ (all data are referred to total membrane area, unless otherwise specified) has been reported for a RE system operated with a standard grade electrodialysis membrane compartments filled with a coal-mine brine and fresh water. ${ }^{10}$ Theoretical models predict that a power density up to $8.5 \mathrm{~W} \mathrm{~m}^{-2}$ is achievable by appropriate optimization and use of specially developed AEM and CEM membranes in contact with brine and seawater solutions. ${ }^{1}$ However, the behaviour of a RE system might vary significantly when operated with real solutions. From eqn (1) it is possible to roughly envisage the different levels of influence of the monovalent and multivalent ions on the open circuit voltage generated by SGP-RE. Assuming apparent membrane permselectivity and activity coefficients constant, the electrochemical potential generated by monovalent ions (almost all investigations in literature focus on $\mathrm{Na}^{+}$ and $\mathrm{Cl}^{-}$) is about twice as large as the one produced by divalent ions $\left(\mathrm{Mg}^{2+}\right.$ and $\mathrm{Ca}^{2+}$ are among the most abundant ions in natural water) when operating at equal ion concentration ratio. Therefore, the sensitivity of a SGP-RE system to real feed conditions is crucial for practical applications.

To date, literature lacks systematic and adequate information on the effect of the simultaneous presence of ions other than sodium and chloride on SGP-RE performance. Vermaas et al. (2014) observed that, when using a mixture with a molar fraction of $10 \% \mathrm{MgSO}_{4}$ and $90 \%$ of $\mathrm{NaCl}$ in both LCC and HCC, experimentally obtained power density in steady state decreased from $29 \%$ to $50 \%$ compared to the case, in which the feed solutions contained only $\mathrm{NaCl}$ as a salt. ${ }^{11}$ An increase in stack resistance because of the addition of $\mathrm{Mg}^{2+}$ ions into sodium chloride solution was also noticed by Post et al. (2009). ${ }^{\mathbf{1 2}}$ Further experimental investigation is needed in order to define clearly the potentialities of the SGP-RE technology and to take a decisive step towards real applications.

In the present work, with the aim to investigate realistic high-salinity conditions, in which sodium, magnesium, calcium, chloride, sulfate, and bicarbonate are the most common and abundant salt ions in natural waters, experiments have been carried out using brackish water and brine from solar ponds (Sicily, Italy) as a sources for low concentration compartment (LCC) and high concentration compartment (HCC) of a SGP-RE unit, respectively. The effect of ionic composition on SGP-RE was evaluated by the measurement of current, voltage and power density.

\section{Materials and methods}

\section{Reverse electrodialysis stack}

Experimental tests were carried out on a SGP-RE stack (Fig. 1a) provided by REDstack B.V (The Netherlands). The stack, operating in a cross-flow configuration, has an active membrane area of $0.01 \mathrm{~m}^{2}(10 \mathrm{~cm} \times 10 \mathrm{~cm})$ and 25 cell pairs. The module was equipped with $270 \mu \mathrm{m}$ polyethylene gaskets and PET a)

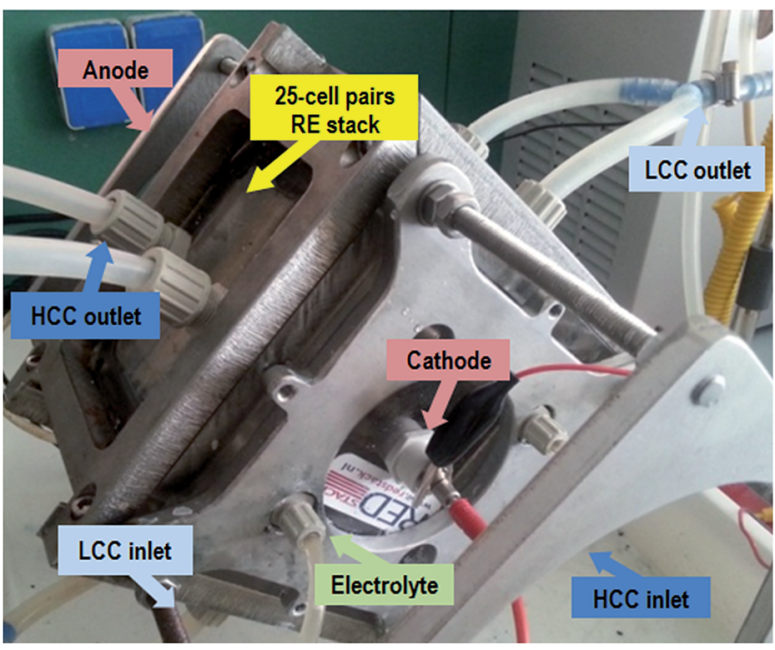

b)

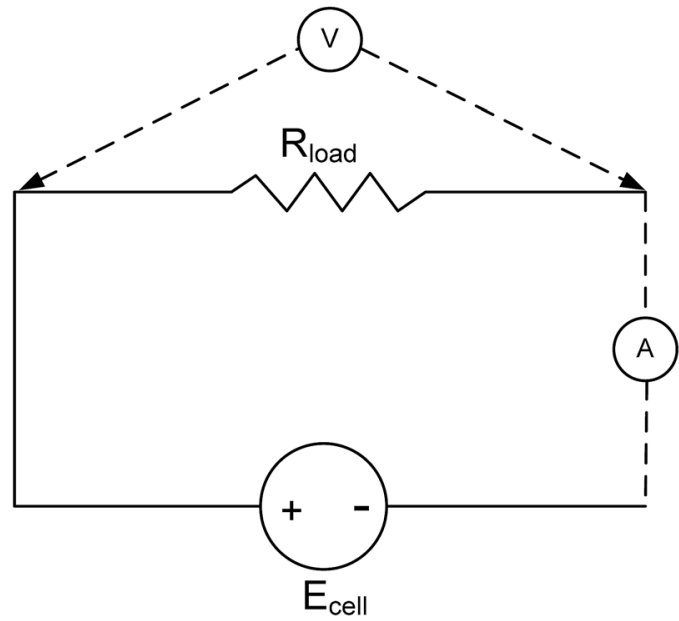

Fig. 1 a) The cross-flow stack used in SGP-RE experiments. (b) Electric circuit diagram of the experimental apparatus. The ammeter $(A)$ is connected in series and voltmeter $(V)$ connecter in parallel with the resistance box $\left(R_{\text {load }}\right)$.

spacers (Deukum GMBH, Germany). Anode and cathode made of inert Ti-Ru/Ir mesh had a dimension of $10 \mathrm{~cm} \times 10 \mathrm{~cm}$ (MAGNETO Special Anodes B.V., The Netherlands). All experiments were carried out at $20^{\circ} \mathrm{C}$.

\section{Membranes}

The ion exchange membranes (IEM) used are AEM-80045 and CEM-80050 provided by Fujifilm Manufacturing Europe B.V (The Netherlands). The membranes were activated in a $0.1 \mathrm{M}$ $\mathrm{NaCl}$ solution before use and stored in the same solution in the stack during the intervals of the testing periods. Membrane characteristics are summarized in Table $1 .^{\mathbf{1 3}}$

\section{Electrolyte and testing solutions}

The electrolyte solution, recirculated throughout the electrolytic compartments at $30 \mathrm{~L} \mathrm{~h}^{-1}$ by Masterflex L/S digital peristaltic 
Table 1 Relevant properties of ion exchange membranes ${ }^{13}$

\begin{tabular}{lcccc}
\hline Membrane code & Thickness $^{a}(\mu \mathrm{m})$ & $\begin{array}{l}\text { Ion exchange capacity } \\
\left(\mathrm{mmol} \mathrm{g}{ }^{-1} \text { membrane }\right)\end{array}$ & $\begin{array}{l}\text { Density of fixed charges }{ }^{a} \\
\left(\mathrm{~mol} \mathrm{~L}^{-1}\right)\end{array}$ & $\begin{array}{l}\text { Membrane area resistance }^{b} \\
\left(\Omega \mathrm{cm}^{2}\right)\end{array}$ \\
\hline Fuji-AEM-80045 & $129 \pm 2$ & $1.4 \pm 0.1$ & $3.8 \pm 0.2$ & $1.551 \pm 0.001$ \\
Fuji-CEM-80050 & $114 \pm 2$ & $1.1 \pm 0.1$ & $2.4 \pm 0.2$ & $2.974 \pm 0.001$ \\
\multicolumn{2}{l}{${ }^{a}$ Measurement conditions: NaCl $0.5 \mathrm{M}, 20 \mathrm{C}^{b}{ }^{b}$ Measurement conditions: NaCl $0.5 \mathrm{M}, 20{ }^{\circ} \mathrm{C}, 2.8 \mathrm{~cm} \mathrm{~s}^{-1}}$.
\end{tabular}

Table 2 Ion composition of real brackish water and brine from solar pond $\left(20^{\circ} \mathrm{C}\right)$. Source: Ettore Infersa evaporation salt pond (Sicily, Italy)

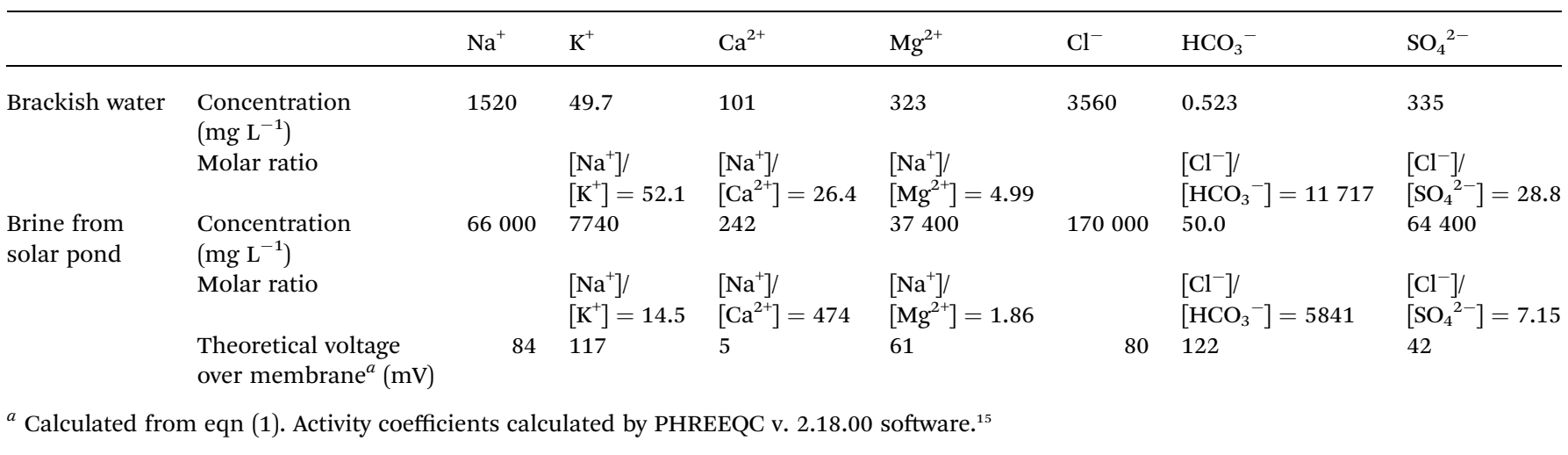

pumps (Cole-Palmer, US), was prepared by dissolving potassium hexacyanoferrate(II), potassium hexacyanoferrate(III) and sodium chloride (Sigma-Aldrich S.r.l., Italy) in deionized water (PURELAB, Elga LabWater®, $0.055 \mu \mathrm{S} \mathrm{cm}^{-1}$ ) up to a final concentration of $0.3 \mathrm{M} \mathrm{K}_{4} \mathrm{Fe}(\mathrm{CN})_{6}, 0.3 \mathrm{M} \mathrm{K}_{3} \mathrm{Fe}(\mathrm{CN})_{6}$ and $2.5 \mathrm{M}$ $\mathrm{NaCl}$.

Testing solutions (composition in Table 2) were prepared by dissolving the following reagent grade salts: $\mathrm{NaHCO}_{3}, \mathrm{KCl}$ and $\mathrm{Na}_{2} \mathrm{SO}_{4}$ purchased from Sigma Aldrich S.r.l. (Italy); $\mathrm{NaCl}$, $\mathrm{CaCl}_{2} \cdot 2 \mathrm{H}_{2} \mathrm{O}$ and $\mathrm{MgCl}_{2} \cdot 6 \mathrm{H}_{2} \mathrm{O}$ from Carlo Erba Reagenti (Italy) in deionized water.

Salt solutions were recirculated throughout the SGP-RE system at a flow rate of $20 \mathrm{~L} \mathrm{~h}^{-1}$ by Masterflex L/S digital peristaltic pumps Mod. no. 7528-10 6-600 rpm (Cole-Palmer, US). Heated circulating baths (PolyScience, US) were used to control the temperature of recirculating streams; temperature at the six inlets of the module was monitored by Multichannel data logging thermometers type K 800024 with high full scale accuracy of $\pm 0.5 \% \mathrm{rdg}$ (Sper Scientific, US). The conductivity of the solutions was measured by YSI (US) model 3200 Conductivity Instrument.

\section{Electrochemical measurements}

A high dissipation five-decade resistance box in the range of 0.1-1000 $\Omega$ (CROPICO, Bracken Hill, US) was used to load the SGP-RE system. DC voltage drop across the load resistors was measured by a $3 \frac{1}{2}$ digital multimeter with accuracy of $\pm 0.5 \%$ in the range of $200 \mathrm{mV}$ to $200 \mathrm{~V}$ (Valleman, DVM760), and the current flowing across the load resistors was measured by Agilent $34422 \mathrm{~A} 6 \frac{1}{2}$ digit multimeter, according to the circuit diagram provided in Fig. $1 \mathrm{~b}$. All the measurements were carried out under continuous operation. The performance of the
SGP-RE unit was evaluated in terms of voltage $(V)$, current $(I)$ and power density $\left(P_{\mathrm{d}}\right)$. The experimental points $V v s$. $I$ were fit by a straight line having the following equation:

$$
V(I)=\mathrm{OCV}-R_{\text {stack }} I
$$

in which open circuit voltage OCV is evaluated at the intersection of $V(I)$ with the voltage axis $(I=0)$, and $R_{\text {stack }}$ is the stack resistance (the slope of the straight line). The intercept of $V(I)$ with the current axis $(V=0)$ represents the shortcut current $I_{\text {shortcut }}$. The calculated electric power density $P_{\mathrm{d}}$ (expressed in terms of $\mathrm{W} \mathrm{m}^{-2}$ of the AEM and CEM pair) plotted as a function of the current density $i$ shows a typical parabolic trend.

It is noteworthy to mention that power density is equal to zero when the current is equal to zero (open circuit condition) or when the voltage is equal to zero (shortcut current condition).

Ion chromatography (IC) was used to evaluate the variation in the composition of LCC dilute solutions after one hour of SGP-RE operation in batch mode.

Cation and anion analysis were performed by 861 Advanced compact ion chromatograph (Metrohom Italiana SrL, Italy) and data processed by ICNet 2.3 software. For cation analysis, Metrosep A Supp 5 250/4.0 column and Metrosep A Supp 4/5 Guard precolumn were used with eluent solution $2 \mathrm{mM} \mathrm{HNO}_{3} / 0.25$ $\mathrm{mM}$ oxalic acid. For anion analysis, Metrostep C4-250/4.0 column and Metrostep C 4 Guard precolumns were used, with $3.2 \mathrm{mM} \mathrm{Na}_{2} \mathrm{CO}_{3} / 1 \mathrm{mM} \mathrm{NaHCO}$ as the eluent solution.

\section{Results and discussion}

\section{Reference test with $\mathrm{NaCl}$}

SGP-RE performance was preliminarily checked by feeding aqueous $\mathrm{NaCl}$ solutions (LCC: $0.1 \mathrm{M}$; HCC: $5 \mathrm{M}$ ). According to 
a)

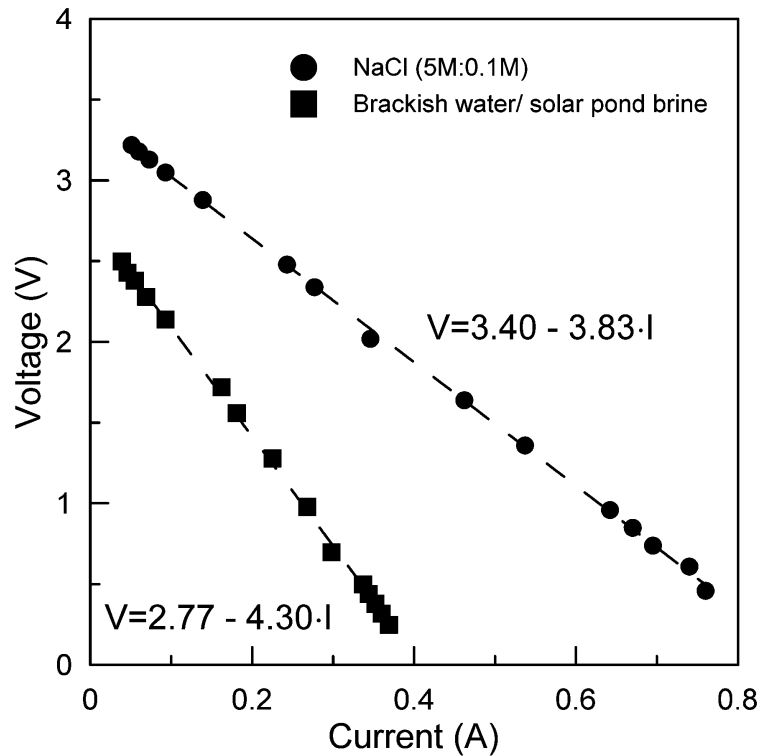

b)

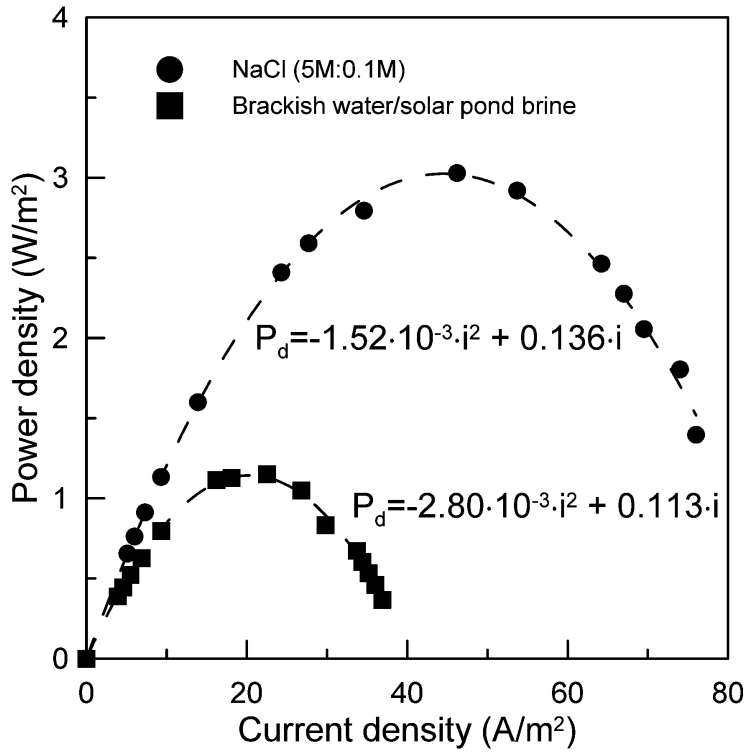

Fig. 2 a) Voltage vs. current; (b) gross power density vs. current density. Data collected under reference conditions: $\mathrm{NaCl}$ solution (0.1 M/0.5 M). Temperature: $20^{\circ} \mathrm{C}$. Margin of error within $10 \%$.
Fig. 2a, the measured OCV was $3.4 \mathrm{~V}$ and $I_{\text {shortcut }}=0.89 \mathrm{~A}$. The power density curve shown in Fig. $2 \mathrm{~b}$ is fitted by eqn (3) for $a=$ $1.52 \times 10^{-3}$ and $b=0.136$. Under these conditions, the system was able to provide a maximum gross power density of $3.04 \mathrm{~W}$ $\mathrm{m}^{-2}$ in correspondence to a current density of $44.7 \mathrm{~A} \mathrm{~m}^{-2}$. The maximum gross power density generated under these conditions was assumed as a reference for the system operated with multi-ion solutions.

Kim and Logan (2011) showed an innovative microbial reverse-electrodialysis unit (5-cells stack), when operated with typical seawater $(600 \mathrm{mM} \mathrm{NaCl})$ and river water $(12 \mathrm{mM} \mathrm{NaCl})$ solutions at $0.85 \mathrm{~mL} \mathrm{~min}^{-1}$, produced up to $3.6 \mathrm{~W} \mathrm{~m}^{-2}$ (cathode surface area) and 1.2-1.3 V with acetate as a substrate; a higher flow rate $\left(1.55 \mathrm{~mL} \mathrm{~min}^{-1}\right)$ resulted in power densities up to $4.3 \mathrm{~W} \mathrm{~m}^{-2} \cdot 16$

In a comparative study between reverse electrodialysis and pressure retarded osmosis, both considered for applications on seawater and river water, Post et al. (2007) calculated a potential maximum power density for SGP-RE in the range of 2-4 $\mathrm{W} \mathrm{m}^{-2}$.

Using a 50-cells stack, a power density of $0.93 \mathrm{~W} \mathrm{~m}^{-2}$ was obtained by Veerman and colleagues (2009) with artificial river water $\left(1 \mathrm{~g} \mathrm{~L}^{-1} \mathrm{NaCl}\right)$ and artificial sea water $\left(30 \mathrm{~g} \mathrm{~L}^{-1} \mathrm{NaCl}\right){ }^{4}$

Daniilidis et al. (2014) achieved a power density of $6.7 \mathrm{~W} \mathrm{~m}^{-2}$ of total membrane area using $0.01 \mathrm{M} \mathrm{NaCl}$ solution against $5 \mathrm{M}$ at $60{ }^{\circ} \mathrm{C}$, in general, the power density was found to increase monotonically for highly concentrated feed solutions. ${ }^{17}$

Theoretical predictions on a 12-cells stack equipped with Fujifilm ion exchange membranes and operated with $0.5 \mathrm{M} / 5.4$ $\mathrm{M} \mathrm{NaCl}$ diluate/concentrate solutions resulted in a maximum gross power density of $2.4 \mathrm{~W} \mathrm{~m}^{-2} \cdot{ }^{4} \mathrm{~A}$ maximum gross power density of $2.2 \mathrm{~W} \mathrm{~m}^{-2}$ was measured in a stack having an intermembrane distance of $100 \mu \mathrm{m}$ using $0.507 \mathrm{M} \mathrm{NaCl}$ as artificial seawater and $0.017 \mathrm{M} \mathrm{NaCl}$ as artificial river water. ${ }^{7}$

\section{Tests on brackish water/solar pond brine}

SGP-RE performance was then evaluated using artificial brackish water (fed to LCC) and exhaust brine from a solar pond (fed to HCC) according to the composition detailed in Table 2. Experimental data reported in Fig. 2a and b show a significant reduction in the maximum gross power density generated by

Table 3 Molar composition of binary LCC/HCC solutions used to investigate the effect of individual ions in the presence of $\mathrm{NaCl}$

\begin{tabular}{|c|c|c|c|}
\hline \multirow[b]{2}{*}{ LCC solution composition } & \multirow[b]{2}{*}{ HCC solution composition } & \multicolumn{2}{|c|}{ Parameters in eqn (2) } \\
\hline & & OCV (V) & $R_{\text {stack }}(\Omega)$ \\
\hline $0.1 \mathrm{M} \mathrm{NaCl}$ & $5 \mathrm{M} \mathrm{NaCl}$ & 3.40 & 3.83 \\
\hline $0.0999975 \mathrm{M} \mathrm{NaCl}+8.5 \times 10^{-6} \mathrm{M}$ & $4.99915 \mathrm{M} \mathrm{NaCl}+8.5 \times 10^{-4} \mathrm{M}$ & 3.39 & 3.79 \\
\hline $\mathrm{NaHCO}_{3}\left[\mathrm{Cl}^{-}\right] /\left[\mathrm{HCO}_{3}{ }^{-}\right]=11717$ & $\mathrm{NaHCO}_{3}\left[\mathrm{Cl}^{-}\right] /\left[\mathrm{HCO}_{3}{ }^{-}\right]=5841$ & & \\
\hline $\begin{array}{l}0.098 \mathrm{M} \mathrm{NaCl}+0.002 \mathrm{M} \mathrm{KCl}\left[\mathrm{Na}^{+}\right] / \\
{\left[\mathrm{K}^{+}\right]=52.1}\end{array}$ & $\begin{array}{l}4.68 \mathrm{M} \mathrm{NaCl}+0.32 \mathrm{M} \mathrm{KCl}\left[\mathrm{Na}^{+}\right] / \\
{\left[\mathrm{K}^{+}\right]=14.5}\end{array}$ & 3.40 & 4.08 \\
\hline $\begin{array}{l}0.096 \mathrm{M} \mathrm{NaCl}+0.004 \mathrm{M} \mathrm{CaCl}_{2}\left[\mathrm{Na}^{+}\right] / \\
{\left[\mathrm{Ca}^{2+}\right]=26.4}\end{array}$ & $\begin{array}{l}4.99 \mathrm{M} \mathrm{NaCl}+0.01 \mathrm{M} \mathrm{CaCl}_{2}\left[\mathrm{Na}^{+}\right] / \\
{\left[\mathrm{Ca}^{2+}\right]=474}\end{array}$ & 3.27 & 3.84 \\
\hline $\begin{array}{l}0.0966 \mathrm{M} \mathrm{NaCl}^{0} 0.0034 \mathrm{M} \mathrm{Na}_{2} \mathrm{SO}_{4} \\
{\left[\mathrm{Cl}^{-}\right] /\left[\mathrm{SO}_{4}{ }^{2-}\right]=28.8}\end{array}$ & $\begin{array}{l}4.39 \mathrm{M} \mathrm{NaCl}+0.61 \mathrm{M} \mathrm{Na}_{2} \mathrm{SO}_{4}\left[\mathrm{Cl}^{-}\right] / \\
{\left[\mathrm{SO}_{4}{ }^{2-}\right]=7.15}\end{array}$ & 3.40 & 4.15 \\
\hline $\begin{array}{l}\mathrm{NaCl} 0.083 \mathrm{M}+\mathrm{MgCl}_{2} 0.017 \mathrm{M} \\
{\left[\mathrm{Na}^{+}\right] /\left[\mathrm{Mg}^{2+}\right]=4.99}\end{array}$ & $\begin{array}{l}\mathrm{NaCl} 3.25 \mathrm{M}+\mathrm{MgCl}_{2} 1.75 \mathrm{M}\left[\mathrm{Na}^{+}\right] / \\
{\left[\mathrm{Mg}^{2+}\right]=1.86}\end{array}$ & 2.73 & 6.69 \\
\hline
\end{tabular}


the SGP-RE stack. Considering the value of $3.04 \mathrm{~W} \mathrm{~m}^{-2}$ as a reference (recorded when operating with pure $\mathrm{NaCl}$ solutions), it was found that $P_{\mathrm{d}, \max }$ decreased down to $1.13 \mathrm{~W} \mathrm{~m}^{-2}$ in correspondence to a current density of $20.1 \mathrm{~A} \mathrm{~m}^{-2}$ when operating with artificial brackish water/brine solutions. Moreover, the $-63 \%$ power density reduction was accompanied by an increase of $76 \%$ in stack resistance (from 3.83 to $6.76 \Omega$ ), whereas OCV and shortcut current decreased to $2.77 \mathrm{~V}$ and 0.41 A, respectively.

\section{Effect of other ions}

In order to discriminate the effect of multiple ions on the drastic reduction of power density generated by the SGP-RE unit operated with real solutions, the combined effect of each single cation $\left(\mathrm{X}^{\nu+}\right)$ and anion $\left(\mathrm{Y}^{\xi-}\right)$ in the presence of $\mathrm{NaCl}$ was investigated, and binary solutions were prepared according to the compositions reported in Table 3. The ratios $\left[\mathrm{Cl}^{-}\right] /\left[\mathrm{Y}^{\xi-}\right]$ and $\left[\mathrm{Na}^{+}\right] /\left[\mathrm{X}^{\nu+}\right]$ within solutions fed to LCC and HCC were maintained the same as in brackish water and brine, respectively. The trend of voltage, current and power density when the SGP$\mathrm{RE}$ was operated with multi-ion solutions is shown in Fig. 3a and $b$. The observed effect of $\mathrm{HCO}_{3}{ }^{-}$on SGP-RE performance was negligible because of the very low concentration of bicarbonate ion in both LCC $\left(8.5 \times 10^{-6} \mathrm{M}\right)$ and HCC $\left(8.5 \times 10^{-4} \mathrm{M}\right)$. As a result, the OCV remained substantially unchanged $(3.39 \mathrm{~V})$, as well as $I_{\text {shortcut }}(0.89 \mathrm{~A})$ and $P_{\mathrm{d}, \max }\left(3.03 \mathrm{~W} \mathrm{~m}^{-2}\right)$.

Despite its significant concentration in the brine $(0.32 \mathrm{M})$, the impact of $\mathrm{K}^{+}$on the power density was quite limited because of the similar electrochemical properties of $\mathrm{Na}^{+}$and $\mathrm{K}^{+}$ions, listed as follows: ionic radii of unhydrated $\mathrm{Na}^{+}$and $\mathrm{K}^{+}$are $1.17 \AA$ and $1.64 \AA$, respectively; ionic radii of hydrated $\mathrm{Na}^{+}$and $\mathrm{K}^{+}$are $3.58 \AA$ and $3.32 \AA$, respectively; ${ }^{18}$ ion diffusion coefficients in water for $\mathrm{Na}^{+}$and $\mathrm{K}^{+}$are $1.334 \times 10^{-9} \mathrm{~m}^{2} \mathrm{~s}^{-1}$ and $1.957 \times 10^{-9}$ $\mathrm{m}^{2} \mathrm{~s}^{-1}$, respectively. ${ }^{19}$ Although no appreciable difference in OCV was observed, $I_{\text {shortcut }}$ moderately decreased to $0.83 \mathrm{~A}$ $(-6.7 \%)$ and $R_{\text {stack }}$ increased to $4.08 \Omega(+6.5 \%)$. The maximum power density $\left(2.84 \mathrm{~W} \mathrm{~m}^{-2}\right)$ was reached at a current density of $41.8 \mathrm{~A} \mathrm{~m}^{-2}$.

Because of its propensity to form sparingly soluble $\mathrm{CaSO}_{4}$ and to precipitate from solution, $\mathrm{Ca}^{2+}$ is generally present in natural waters only at relatively low concentration. As a consequence, for the investigated LCC/HCC composition of $0.004 \mathrm{M} / 0.096 \mathrm{M} \mathrm{CaCl}_{2}$, both OCV and power density were affected in a limited extent ( $-4 \%$ and $-6.6 \%$ with respect to pure $\mathrm{NaCl}$, respectively). The concentration of sulphate and magnesium ions is typically highest after $\mathrm{Na}^{+}$and $\mathrm{Cl}^{-}$in brine, seawater and brackish water. However, the presence of $\mathrm{SO}_{4}{ }^{2-}$ did not significantly change OCV and resulted in a moderate decrease of $I_{\text {shortcut }}(0.82 \mathrm{~A})$ and $P_{\mathrm{d}, \max }$ (2.79 $\mathrm{W} \mathrm{m}^{-2},-8.2 \%$ with respect to pure $\mathrm{NaCl}$ ).

On the other hand, the presence of magnesium drastically decreased both OCV $(2.73 \mathrm{~V},-20 \%$ with respect to pure $\mathrm{NaCl})$ and power density $\left(1.11 \mathrm{~W} \mathrm{~m}^{-2},-64 \%\right.$ with respect to pure $\mathrm{NaCl}$ ). The measured value of $i_{\mathrm{Pd}, \max }=20.2 \mathrm{~A} \mathrm{~m}^{-2}$ was lowest. The effect of magnesium valence on the reduced electrical potential difference has been already anticipated when introducing eqn (1). a)

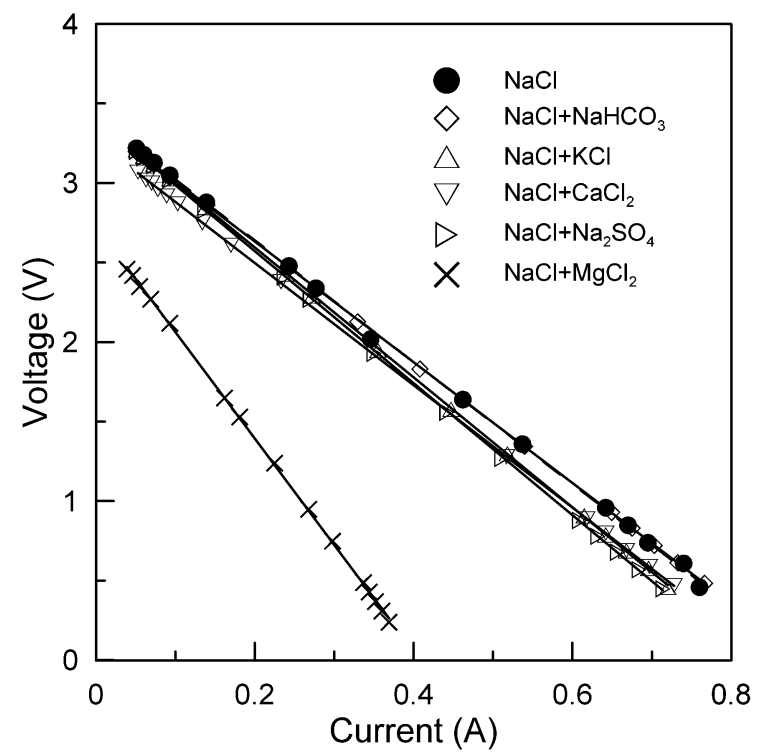

b)

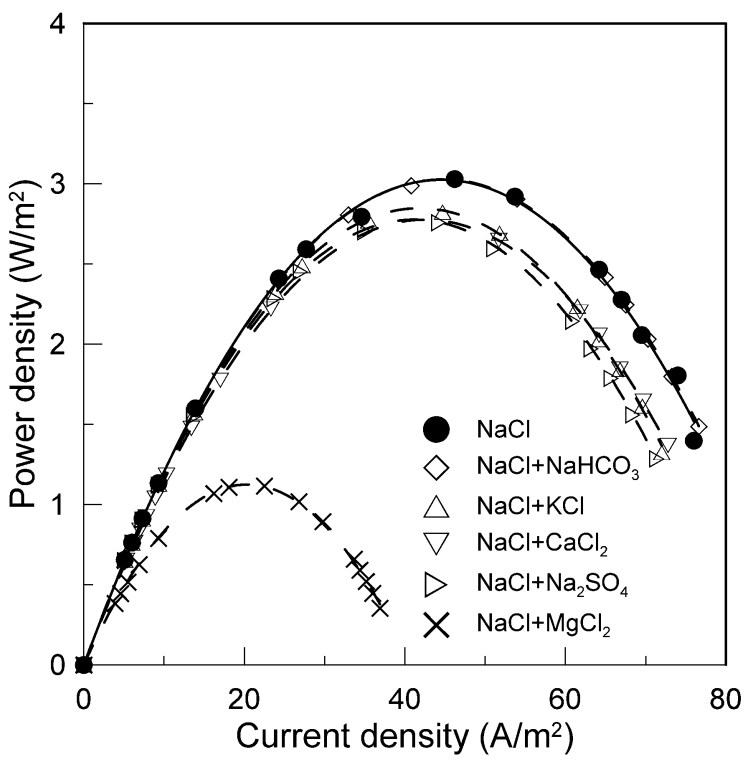

Fig. 3 a) Voltage vs. current; (b) gross power density vs. current density for multi-ion solutions. Compositions are detailed in Table 3. Temperature: $20^{\circ} \mathrm{C}$. Margin of error within 10\% (average of 3 tests).

Moreover, the significant enhancement of the cell resistance may be attributed to an increase in membrane resistance in the presence of $\mathrm{Mg}^{2+}$. Sata (2004) reported a two- to three-fold increase in electrical resistance for different commercial cation exchange membranes (NEOSEPTA CL-25T, AMFion C-310, Ionac MC-3470) when using $\mathrm{MgCl}_{2}$ instead of $\mathrm{NaCl}$. An enhancement in the electrical resistance of the membranes with the concentration of the electrolyte solution was also because of the increase in Donnan adsorbed salts and shrinking of the membranes. ${ }^{20}$

A systematic investigation of this aspect, based on the electrochemical impedance spectroscopy, ${ }^{\mathbf{1 3}, 14}$ will be the objective of future communications. 


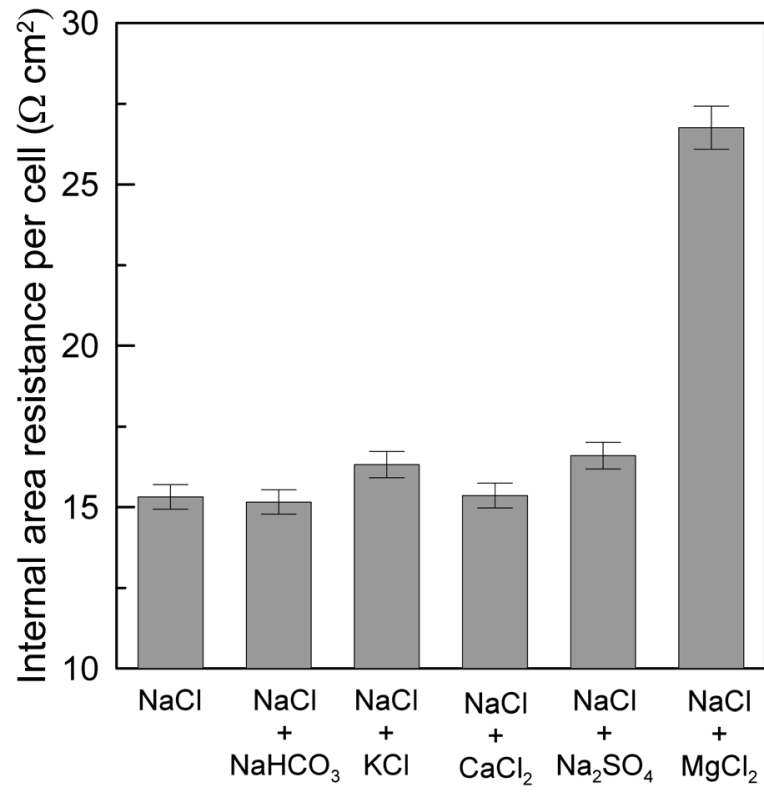

Fig. 4 Internal area resistance per cell for the binary solutions investigated (single membrane area: $100 \mathrm{~cm}^{2}$; number of cell pairs: 25).

\section{Stack resistance}

A significant advantage gained when operating SGP-RE at high salt concentration is the reduction of the electrical resistance compared to the extensively studied case of low salt concentration (i.e. combination river water/seawater). The extent of the internal area resistance (IAR) per cell for the different tested solutions is presented in Fig. 4.

These results show a lower IAR per cell of SGP-RE stack (below $26.8 \Omega \mathrm{cm}^{2}$ ) compared to previous investigations on RE operated with a river water/seawater solutions pair, which was above $50 \Omega \mathrm{cm}^{2}$ in most cases. ${ }^{3,4,18}$ With respect to the reference $\mathrm{NaCl}$ solutions $\left(R_{\text {stack }}=3.83 \Omega, \mathrm{IAR}=15.32 \Omega \mathrm{cm}^{2}\right)$, significant variations in electrical resistance were observed only for $\mathrm{NaCl}+$ $\mathrm{MgCl}_{2}$ solutions. In this case, the presence of magnesium increased the resistance of the stack $(6.69 \Omega)$ and IAR $(26.8 \Omega$ $\mathrm{cm}^{2}$ ) by $75 \%$, resulting in a drastic decrease of $64 \%$ in power density.

\section{Transport of ions}

Ion chromatography was used to check the variation of ion composition in feed solutions as a result of the migration of ions through IEM driven by an electrochemical potential. Experimental tests were carried out in batch mode by recycling both artificial brackish water and artificial brine over the stack under open-circuit conditions (absence of net flux of electrical charges) and collecting the samples after 1 hour.

Only the solution flowing in the low concentration compartment was analyzed because of the large measurement errors related to the small variations in the highly concentrated brine.

Results reported in Table 4 show an increase in the overall concentration of LCC in the investigated interval of time, and the total mass of the dissolved ions increases by $164 \%$ from 6970 to $18400 \mathrm{mg} \mathrm{L}^{-1}$. Within a narrow margin of measurement error $(2 \%)$, the charge balance after migration of ions is satisfied (total positive charge $=329 \mathrm{meq} \mathrm{L}^{-1}$. Total negative charge $=323$ meq L $^{-1}$ ).

Fig. 5 illustrates the transport rate of each ion as a function of its concentration in HCC compartment.

Because of the nonideal behavior of the membranes, having perselectivity lower than $100 \%$, a combined transport of both cations and anions can occur. It is interesting to compare transport rate and theoretical voltage over membrane for each ion reported in Table 2. The measured OCV for the SGP-RE stack operated with brackish water/solar pond brine was $2.77 \mathrm{~V}$ (Fig. 2a), thus implying a membrane voltage of $55 \mathrm{mV}$. Most of the voltages reported in Table 2 are higher than $55 \mathrm{mV}$, indicating a forward transport. Exceptions are for divalent ions $\mathrm{Ca}^{2+}$ and $\mathrm{SO}_{4}{ }^{2-}$, in which expected back-transport is not observed because of the effect of multiple co-ion transport. When considering all ions, the overall electrochemical balance is satisfied within an acceptable confidence interval (7\%).

The diffusion of $\mathrm{Na}^{+}$resulted in a concentration increase of $155 \%$ for an initial HCC/LCC Na ${ }^{+}$concentration ratio of 34 ; a similar concentration increase $(+152 \%)$ was found for chlorine with an initial $\mathrm{HCC} / \mathrm{LCC} \mathrm{Cl}^{-}$concentration ratio of 47.8. These data seem to confirm that ion migration through ion exchange membranes is substantially driven by a concentration gradient.

Table 4 Ion composition (from Ion Chromatography analysis) of the low-concentration stream in SGP-RE batch operation (LCC: artificial brackish water; HCC: artificial brine) ${ }^{a}$

\begin{tabular}{|c|c|c|c|c|}
\hline \multirow[b]{2}{*}{ Ion } & \multirow{2}{*}{ 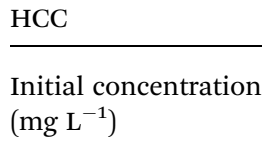 } & \multicolumn{3}{|l|}{ LCC } \\
\hline & & $\begin{array}{l}\text { Initial concentration } \\
\left(\mathrm{mg} \mathrm{L}^{-1}\right)\end{array}$ & $\begin{array}{l}\text { Concentration after } \\
1 \text { hour }\left(\mathrm{mg} \mathrm{L}^{-1}\right)\end{array}$ & $\begin{array}{l}\text { Concentration } \\
\text { increase }\left(\mathrm{mmol} \mathrm{L}^{-1}\right)\end{array}$ \\
\hline $\mathrm{Na}^{+}$ & 66000 & 1520 & 3870 & 102 \\
\hline $\mathrm{K}^{+}$ & 7740 & 49.7 & 478 & 11 \\
\hline $\mathrm{Mg}^{2+}$ & 37400 & 323 & 1740 & 58 \\
\hline $\mathrm{SO}_{4}^{2-}$ & 64400 & 335 & 3380 & 32 \\
\hline
\end{tabular}

${ }^{a}$ Volume of low conc. compartment: $5 \mathrm{~L}$; volume of high conc. compartment: $5 \mathrm{~L}$. Solutions recirculated at $20 \mathrm{~L} \mathrm{~h}{ }^{-1}$. Temperature: $20{ }^{\circ} \mathrm{C}$. Data averaged on 3 measurements. 


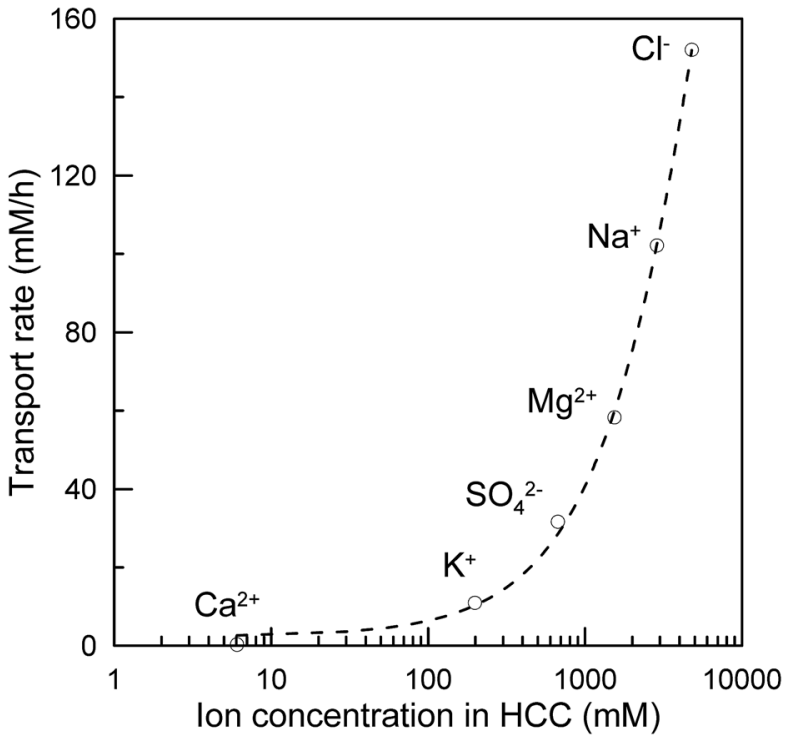

Fig. 5 Transport rate of single ions versus their concentration in brine compartment.

In highlighting the experiments on ion transport carried out by Post et al. (2009), in which the LCC solution consisted of $3 \mathrm{mM}$ $\mathrm{NaCl}+2 \mathrm{mM} \mathrm{MgSO}_{4}$ and the HCC of $0.45 \mathrm{M} \mathrm{NaCl}+0.05 \mathrm{M}$ $\mathrm{MgSO}_{4}$, an almost two-fold increase of sodium and chloride content in the LCC was observed after one hour when operating with standard-grade ion-exchange membranes. ${ }^{\mathbf{1 2}}$

Moreover, our measurements indicate that sodium and magnesium are transported across CEM with a flux of 2.84 and $3.24 \mathrm{meq} \mathrm{m}^{-2} \mathrm{~s}^{-1}$, respectively, whereas chlorine and sulfate diffuse across AEM with rates of 4.23 and $1.76 \mathrm{meq} \mathrm{m}^{-2} \mathrm{~s}^{-1}$, respectively.

\section{Conclusions}

A cross-flow SGP-RE stack equipped with AEM-80045 and CEM80050 membranes, when operated with $0.1 \mathrm{M} / 5 \mathrm{M} \mathrm{NaCl}$ solutions, reached a maximum gross power density of $3.04 \mathrm{~W} \mathrm{~m}^{-2}$ at $20{ }^{\circ} \mathrm{C}$ and recirculation rate of $20 \mathrm{~L} \mathrm{~h}^{-1}$. However, a remarkable increase of stack resistance $(+75 \%)$ and a significant loss of maximum power density $(-64 \%)$ were observed when the SGP$\mathrm{RE}$ was operated with feed solutions containing $\mathrm{Mg}^{2+}$ ions (HCC: $\mathrm{NaCl} 3.25 \mathrm{M}+\mathrm{MgCl}_{2} 1.75 \mathrm{M}$; $\left[\mathrm{Na}^{+}\right] /\left[\mathrm{Mg}^{2+}\right]=1.86$; LCC: $\left.\mathrm{NaCl} 0.083 \mathrm{M}+\mathrm{MgCl}_{2} 0.017 \mathrm{M} ;\left[\mathrm{Na}^{+}\right] /\left[\mathrm{Mg}^{2+}\right]=4.99\right)$. The comparable decrease in power density observed for artificial multi-ion solutions, which mimic brackish water and exhaust brine from a solar pond (Ettore Infersa site, Sicily) depicts the necessity for specific softening strategies for a better performance of SGP-RE under real conditions. In this respect, the integration of SGP-RE within pretreatment schemes of typical SWRO desalination plants might represent a feasible and economically viable option for recovering the electrochemical energy intrinsically present into discharged brines.

Moreover, an urgent need for developing specific ion exchange membranes not suffering from magnesium effects is envisaged.

\section{Acknowledgements}

The financial support of the European Union within the project REAPower - "Reverse Electrodialysis Alternative Power Production" under the EU-FP7 programme (Project no. 256736, http:// www.reapower.eu), and the financial support of The Education, Audiovisual and Culture Executive Agency (EACEA) under the Program "Erasmus Mundus Doctorate in Membrane Engineering” - EUDIME (FPA 2011-0014, http://www. eudime.unical.it), are kindly acknowledged.

\section{Notes and references}

1 M. Tedesco, A. Cipollina, A. Tamburini, W. van Baak and G. Micale, Desalin. Water Treat., 2012, 49, 404-424.

2 J. N. Weinstein and F. B. Leitz, Science, 1976, 191, 557-559.

3 P. Dlugolecki, A. Gambier, K. Nijmeijer and M. Wessling, Environ. Sci. Technol., 2009, 43, 6888-6894.

4 J. Veerman, M. Saakes, S. J. Metz and G. J. Harmsen, J. Membr. Sci., 2009, 327, 136-144.

5 J. W. Post, C. H. Goeting, J. Valk, S. Goinga, J. Veerman, H. V. M. Hamelers and P. J. F. M. Hack, Desalin. Water Treat., 2010, 16, 182-193.

6 J. Veerman, M. Saakes, S. J. Metz and G. J. Harmsen, Environ. Sci. Technol., 2010, 44, 9207-9212.

7 D. A. Vermaas, M. Saakes and K. Nijmeijer, Environ. Sci. Technol., 2011, 45, 7089-7095.

8 D. A. Vermaas, J. Veerman, N. Y. Yip, M. Elimelech, M. Saakes and K. Nijmeijer, ACS Sustainable Chem. Eng., 2013, 1, 1295-1302.

9 J. W. Post, J. Veerman, H. V. M. Hamelers, G. J. W. Euverink, S. J. Metz, K. Nymeijer and C. J. N. Buisman, J. Membr. Sci., 2007, 288, 218-230.

10 M. Turek, B. Bandura and P. Dydo, Desalination, 2008, 221, 462-466.

11 D. A. Vermaas, J. Veerman, M. Saakes and K. Nijmeijer, Energy Environ. Sci., 2014, 7, 1434-1445.

12 J. W. Post, H. V. M. Hamelers and C. J. N. Buisman, J. Membr. Sci., 2009, 330, 65-72.

13 E. Fontananova, W. Zhang, I. Nicotera, C. Simari, W. van Baak, G. Di Profio, E. Curcio and E. Drioli, J. Membr. Sci., 2014, 459, 177-189.

14 P. Dlugolecki, P. Ogonowski, S. J. Metz, M. Saakes, K. Nijmeijer and M. Wessling, J. Membr. Sci., 2010, 349, 369-379.

15 D. L. Parkhurst and C. A. L. Appelo, U. S. Geol. Surv., WaterResour. Invest. Rep., 1999, 99-4259, 1-312.

16 Y. Kim and B. E. Logan, Environ. Sci. Technol., 2011, 45, 5834-5839.

17 A. Daniilidis, D. A. Vermaas, R. Herber and K. Nijmeijer, Renewable Energy, 2014, 64, 123-131.

18 A. G. Volkov, S. Paula and D. W. Deamer, Bioelectrochem. Bioenerg., 1997, 42, 153-160.

19 E. Samson, J. Marchand and K. A. Snyder, Mater. Struct., 2003, 36, 156-165.

20 T. Sata, Ion Exchange Membrane, Royal Society of Chemistry, Cambridge UK, 2004. 